University of Nebraska - Lincoln

DigitalCommons@University of Nebraska - Lincoln

Faculty Publications: Department of Entomology

Entomology, Department of

2007

\title{
Cadaver Decomposition in Terrestrial Ecosystems
}

David O. Carter

University of Nebraska-Lincoln, dcarter2@unl.edu

David Yellowlees

James Cook University, Townsville, Australia, david.yellowlees@jcu.edu.au

Mark Tibbett

University of Western Australia, Mark.Tibbett@uwa.edu.au

Follow this and additional works at: https://digitalcommons.unl.edu/entomologyfacpub

Part of the Entomology Commons

Carter, David O.; Yellowlees, David; and Tibbett, Mark, "Cadaver Decomposition in Terrestrial Ecosystems" (2007). Faculty Publications: Department of Entomology. 251.

https://digitalcommons.unl.edu/entomologyfacpub/251

This Article is brought to you for free and open access by the Entomology, Department of at DigitalCommons@University of Nebraska - Lincoln. It has been accepted for inclusion in Faculty Publications: Department of Entomology by an authorized administrator of DigitalCommons@University of Nebraska - Lincoln. 
Published in Naturwissenschaften 94 (2007), pp. 12-24; doi: 10.1007/s00114-006-0159-1

Copyright (C) 2006 Springer-Verlag. Used by permission.

Submitted December 22, 2005; revised July 31, 2006; accepted August 1, 2006; published online November 8, 2006.

\title{
Cadaver Decomposition in Terrestrial Ecosystems
}

\author{
David O. Carter, ${ }^{1,3}$ David Yellowlees, ${ }^{1}$ and Mark Tibbett ${ }^{2}$ \\ 1. School of Pharmacy and Molecular Sciences, James Cook University, Townsville, QLD 4811, Australia \\ 2. Centre for Land Rehabilitation, School of Earth and Geographical Sciences, University of Western Australia, \\ Crawley, WA 6009, Australia \\ 3. Department of Entomology, University of Nebraska-Lincoln, 202 Plant Industry Building, Lincoln, NE \\ 68583-0816, USA \\ Corresponding author - David O. Carter, dcarter2@unl.edu
}

\begin{abstract}
A dead mammal (i.e. cadaver) is a high quality resource (narrow carbon:nitrogen ratio, high water content) that releases an intense, localized pulse of carbon and nutrients into the soil upon decomposition. Despite the fact that as much as 5,000 kg of cadaver can be introduced to a square kilometer of terrestrial ecosystem each year, cadaver decomposition remains a neglected microsere. Here we review the processes associated with the introduction of cadaver-derived carbon and nutrients into soil from forensic and ecological settings to show that cadaver decomposition can have a greater, albeit localized, effect on below-ground ecology than plant and fecal resources. Cadaveric materials are rapidly introduced to below-ground floral and faunal communities, which results in the formation of a highly concentrated island of fertility, or cadaver decomposition island (CDI). CDIs are associated with increased soil microbial biomass, microbial activity ( $C$ mineralization) and nematode abundance. Each CDI is an ephemeral natural disturbance that, in addition to releasing energy and nutrients to the wider ecosystem, acts as a hub by receiving these materials in the form of dead insects, exuvia and puparia, fecal matter (from scavengers, grazers and predators), and feathers (from avian scavengers and predators). As such, CDIs contribute to landscape heterogeneity. Furthermore, CDIs are a specialized habitat for a number of flies, beetles, and pioneer vegetation, which enhances biodiversity in terrestrial ecosystems.
\end{abstract}

Keywords: mammal, carbon cycle, nutrient cycle, forensic taphonomy, scavenging, biodiversity, landscape heterogeneity, postputrefaction fungi

\section{Introduction}

It is estimated that approximately $99 \%$ of the organic resources that undergo decomposition in a terrestrial ecosystem are plant-derived (e.g. leaf litter, root exudates, stems) or fecal matter (Swift et al. 1979). As a consequence, the breakdown of these materials has received a vast amount of attention (e.g. Aarons et al. 2004; Bjornlund and Christensen 2005). In contrast, the decompo- sition of dead mammals (i.e. cadavers) has long been a neglected microsere (Allee et al. 1949). This is in spite of the fact that a large number of mammals die from causes other than predation and leave their cadavers to decompose and nutrients to be recycled. In a Neotropical rainforest (Barro Colorado Island, Panama) (Eisenberg and Thorington Jr. 1973), 5,000 kg of mammal biomass per $\mathrm{km}^{2}$ is associated with $750 \mathrm{~kg}$ of cadavers per year per $\mathrm{km}^{2}$ (Houston 1985). The average annual bison 
(Bos bison L.) biomass in 988 ha of North American tallgrass prairie (Konza Prairie, Kansas, USA) from 1998 to 2004 was 92,432 kg (E. G. Towne, personal communication). An average mortality rate of $5.6 \%$ resulted in an annual bison cadaver input of approximately $5,000 \mathrm{~kg}$ and shows that cadaveric resources might represent more than $1 \%$ of the organic matter input in some terrestrial ecosystems.

Considering that each cadaver is approximately $20 \%$ carbon and acts as a specialized habitat for several organisms, cadaver decomposition is likely an important ecosystem process. It is therefore surprising that little is understood about the fate of cadaver-derived carbon and nutrients (e.g. nitrogen, phosphorus) (Putman 1978b; Vass et al. 1992; Hopkins et al. 2000; Towne 2000; Carter 2005) and cadaver components (e.g. bone, skeletal muscle tissue) (Child 1995; Aturaliya and Lukasewycz 1999; Carter and Tibbett 2006), particularly since carbon sequestration (Janzen 2006), carbon cycle modeling (Fang et al. 2005), soil organic matter formation (Moran et al. 2005) and the relationships between biodiversity and ecosystem function (McCann 2000; Fitter et al. 2005) are at the forefront of ecological research.

Much research into cadaver decomposition is done under the guise of forensic taphonomy. Taphonomy, originally a branch of paleontology, was developed to understand the ecology of a decomposition site, how site ecology changes upon the introduction of plant or animal remains and, in turn, how site ecology affects the decomposition of these materials (Efremov 1940). In recent years, these goals were incorporated by forensic science to understand the decomposition of human cadavers (Rodriguez and Bass 1983; Spennemann and Franke 1995; Carter and Tibbett 2006), to provide a basis on which to estimate postmortem and/or postburial interval (Willey and Snyder 1989; Vass et al. 1992; Higley and Haskell 2001; Tibbett et al. 2004; Megyesi et al. 2005), to assist in the determination of cause and manner of death (Nuorteva 1977; Crist et al. 1997; Haglund and Sorg 1997) and to aid in the location of clandestine graves (Rodriguez and Bass 1985; France et al. 1992; Hunter 1994; France et al. 1997; Carter and Tibbett 2003). These goals are achieved through the study of the factors that influence cadaver decomposition (e.g. temperature, moisture, insect activity). These studies have also provided insight into the below-ground ecology of cadaver breakdown.

The aim of the current work is to review the fundamental processes associated with the formation and ecology of gravesoil. We define gravesoil as any soil that is associated with cadaver decomposition, regardless of the species of mammal or whether decomposition takes place on or in the soil. This definition is based on the original aim of taphonomy to understand the processes associated with the fossilization of animal remains (Efremov 1940). Because gravesoil represents a linkage between aboveground and below-ground ecology, this paper will review the relationships between gravesoils, intrinsic cadaver decomposition processes (autolysis, putrefaction), aboveground insect activity and scavenger activity. As a consequence, more fundamental work can be found on autolysis and putrefaction (Evans 1963b; Coe 1973; Clark et al. 1997; Gill-King 1997; Vass et al. 2002), cadaver associated insect activity (Schoenly and Reid 1987; Campobasso et al. 2001; Amendt et al. 2004) and scavenger activity (Haynes 1980; DeVault et al. 2003, 2004).

\section{The Formation of Gravesoil}

Although soil microbial biomass is recognized as "the eye of the needle" (Jenkinson 1977) through which all organic material eventually passes, little work has focused on cadaver decomposition, below-ground ecology and microbiology (Bornemissza 1957; Putman 1978b; Sagara 1995; Hopkins et al. 2000; Tibbett and Carter 2003). Advances in the understanding of gravesoils are primarily empirical observations (Illingworth 1926; Mant 1950; Evans 1963b; Morovic-Budak 1965; Sagara 1976; Micozzi 1991; Dent et al. 2004) or made during the study of insect and/or scavenger activity (Bornemissza 1957; Reed 1958; Payne 1965; Payne et al. 1968; Rodriguez and Bass 1985; DeVault et al. 2003). These observations and studies showed that introduction of cadaveric material into the soil is primarily regulated by the activity of insects and scavengers and the mass of the cadaver.

Insects, scavengers and microbes compete for cadaveric resources. Insects can consume a cadaver before a scavenger has utilized it (Putman 1978a; DeVault et al. 2004) and microorganisms can release repellent toxins, such as botulin toxin (Janzen 1977). However, scavengers were observed to consume $35 \%$ to $75 \%$ of the cadavers in terrestrial ecosystems (DeVault et al. 2003). When insects and microbes are less active (such as during winter) scavenger success can approach 100\% (Putman 1983). Smaller cadavers (i.e. rodents, juveniles) tend to be consumed ex situ so that the amount of cadaveric material entering the soil might be negligible (Putman 1983). Adult or large cadavers tend to be consumed (at least partly) in situ, which allows cadaveric material to enter the soil (Coe 1978; Towne 2000) or to be left on the soil surface as recalcitrant residues such as hair, nails or desiccated skin (Putman 1983). Thus, significant amounts of cadaveric material might only enter the soil when insects and microbes dominate cadaver decomposition or when a cadaver is too large to be carried away in its entirety by a scavenger. 


\section{Decomposition Stages and Gravesoil Ecology}

The resource-driven selection of the decomposer community (e.g. Beijerinck 1913; Sinsabaugh et al. 2002) was repeatedly observed as the aboveground insect succession associated with cadaver decomposition on the soil surface (Holdaway 1930; Bornemissza 1957; Anderson and VanLaerhoven 1996; Richards and Goff 1997; Kocárek 2003) or the succession of marine trophic groups associated with whale falls on the floor of deepsea ecosystems (Bennett et al. 1994; Smith et al. 1998; Baco and Smith 2003; Smith and Baco 2003). Several cadaver decomposition studies (Payne 1965; Payne et al. 1968; Micozzi 1986; Hewadikaram and Goff 1991; Anderson and VanLaerhoven 1996; Kocárek 2003; Melis et al. 2004; Carter 2005) showed that cadaver breakdown follows a sigmoidal pattern (Figure 1). This decomposition pattern differs from the breakdown of plant and fecal matter, which are better described by an exponential decay curve (Putman 1983; Coleman et al. 2004). The discrepancy between the pattern of cadaver and plant/ fecal decomposition is probably due to the complexity of the substrate and presence of skin, which will retain cadaveric moisture, and the rate at which fly larvae assimilate cadaveric material, which can also follow a sigmoidal pattern (Putman 1977). Although the rate of cadaver breakdown will vary depending on the environment (Mann et al. 1990; Fiedler and Graw 2003; Dent et al. 2004), it was suggested that cadavers might not persist in terrestrial ecosystems as long as fecal matter and woody material (Schoenly and Reid 1987).

The progress of a cadaver through the sigmoidal decomposition pattern is often associated with a number of stages (Fuller 1934; Bornemissza 1957; Reed 1958; Payne 1965; Payne and King 1968; Johnson 1975; Coe 1978; Megyesi et al. 2005). Decomposition stages are a convenient means to summarize physicochemical changes, however, they are subjective and do not typically represent discrete seres (Schoenly and Reid 1987). For consistency we refer to the six stages (Fresh, Bloated, Active Decay, Advanced Decay, Dry, Remains) proposed by Payne (1965). It is important to note that the progress of a cadaver through these stages is typically attributed to temperature. Accumulated degree days (ADDs: the sum of average daily temperature) can be used to compensate for differences in temperature (Vass et al. 1992; Megyesi et al. 2005). Consequently, it is known that "Advanced Decay" and "Remains" associated with a $68 \mathrm{~kg}$ human cadaver occur at 400 and 1,285 ADDs, respectively (Vass et al. 1992). Thus, an average summer daily temperature of $25^{\circ} \mathrm{C}$ would result in the onset of "Advanced Decay" after 16 days while an average daily winter temperature of $5^{\circ} \mathrm{C}$ would result in an onset of "Advanced Decay" after 80 days.

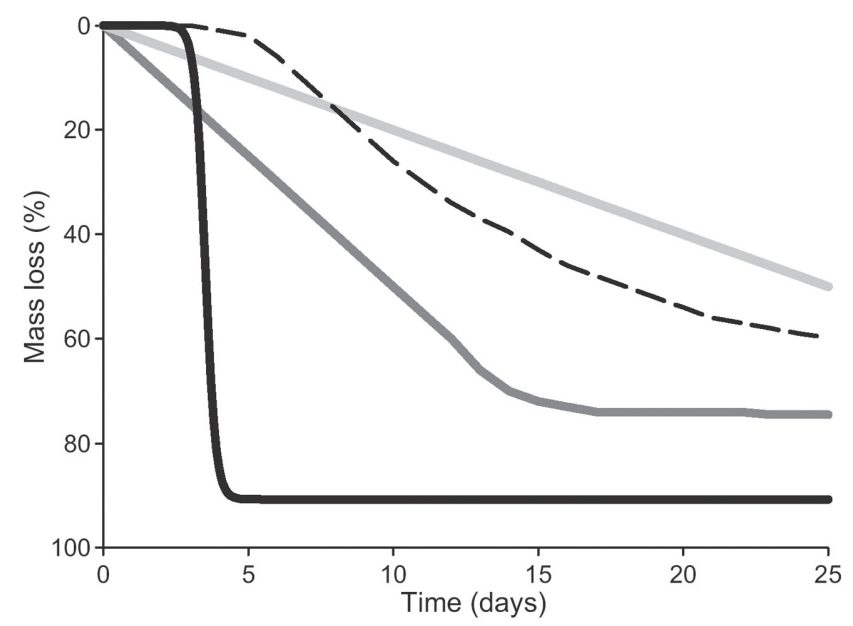

Figure 1. Mass loss curves typically associated with the decomposition of a cadaver on the soil surface $(-)$, buried cadaver (- - ), plant material (-) or fecal (dung) material (-). Cadaver mass loss data was compiled from previous publications: cadaver on soil surface (Payne 1965); buried cadaver (Carter 2005); plant material (Wardle et al. 1994; Coleman et al. 2004); fecal matter (Putman 1983; Esse et al. 2001).

"Fresh" stage decomposition is associated with the cessation of the heart and the depletion of internal oxygen. A lack of oxygen inhibits aerobic metabolism, which causes the destruction of cells by enzymatic digestion (autolysis) (Evans 1963b; Coe 1973; Gill-King 1997). Concomitantly, blow flies (Calliphoridae) and flesh flies (Sarcophagidae) colonize a cadaver to find a suitable site for the development of their offspring. Autolysis (Vass et al. 2002) and fly colonization (Payne 1965; Nuorteva 1977) can begin within minutes of death. Fly oviposition is a vital step in the breakdown of a cadaver as maggot activity is the driving force behind the removal of soft tissue in the absence of scavengers. Indeed, Linnaeus (1767) stated that "three flies could consume a horse cadaver as rapidly as a lion." In addition, soil microbes (possibly zymogenous r-strategist bacteria) were observed to positively respond, as measured by carbon dioxide $\left(\mathrm{CO}_{2}-\mathrm{C}\right)$ evolution (a commonly used index of microbial activity (Ajwa and Tabatabai 1994; Michelsen et al. 2004; Carter and Tibbett 2006)), to cadaver introduction within 24 h (Putman 1978b; Carter 2005).

The depletion of internal oxygen also creates an ideal environment for anaerobic microorganisms (e.g. Clostridium, Bacteroides) originating from the gastrointestinal tract and respiratory system. After the establishment of anaerobiosis, these microorganisms transform carbohydrates, lipids and proteins into organic acids (e.g. propionic acid, lactic acid) and gases (e.g. methane, hydrogen sulfide, ammonia) that result in color change, odor and 
Figure 2. Decomposition of a 10 week old $(\sim 40 \mathrm{~kg})$ pig (Sus scrofa L.) cadaver during the summer of 2005 at the University of Nebraska-Lincoln Agricultural Research and Development Center near Ithaca, NE, USA. (a) Depicts the "Bloated" stage approximately $48 \mathrm{~h}$ after death. The onset of "Active Decay" (b) can be designated by skin ruptures that result in the loss of moisture and increased surface area for maggot development. The release of cadaveric fluids and/or maggot activity results in the formation of a cadaver decomposition island (CDI) that is visible as dead plant material (c: bar represents $1 \mathrm{~m})$. The arrow denotes the path and direction of maggot migration. Approximately 80 days after death the cadaver decomposition island (CDI) is surrounded by an area of increased plant growth (d), which might be used as a marker for the onset of the "Dry" stage of decomposition.
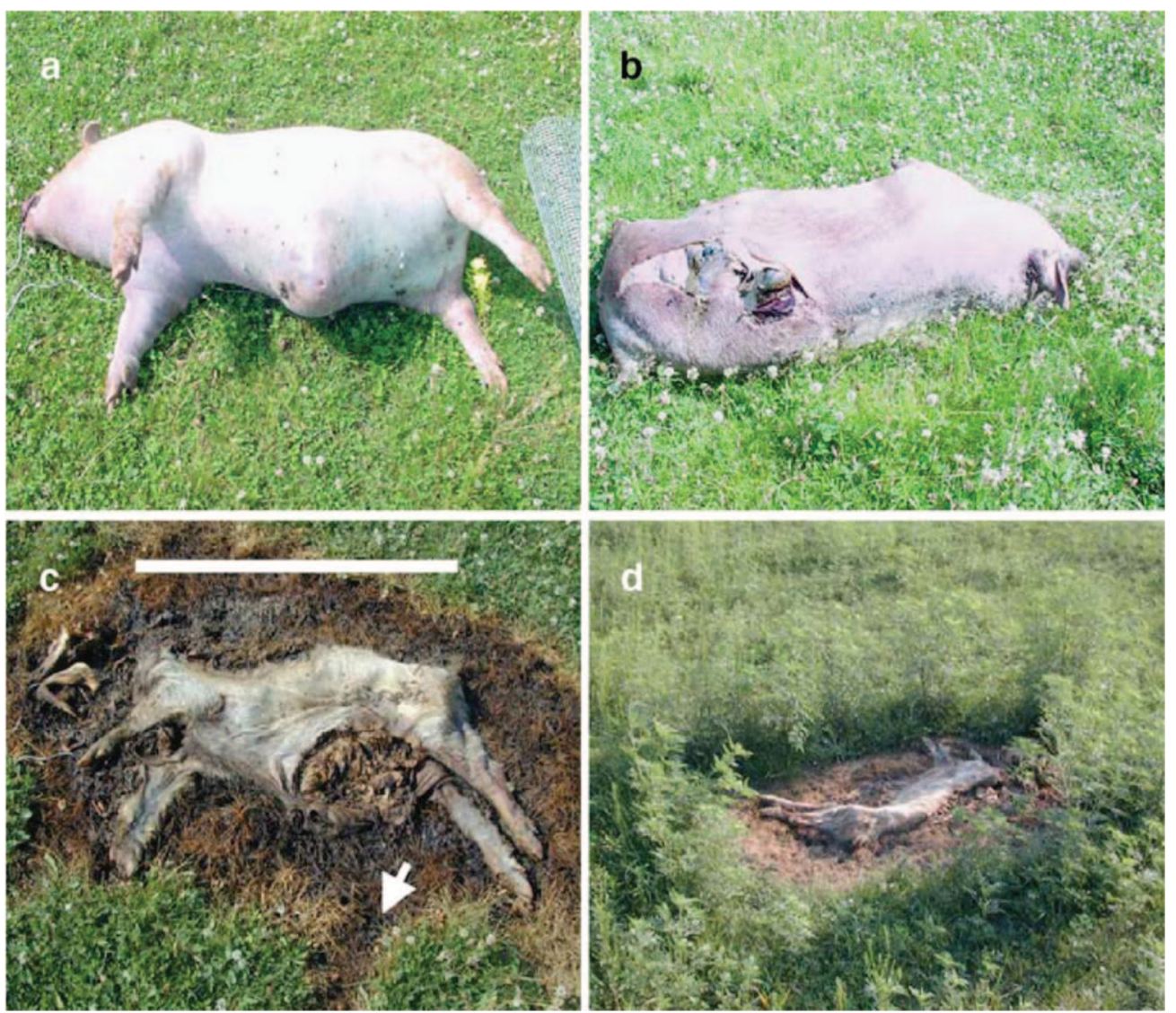

bloating of the cadaver (Clark et al. 1997). This process is putrefaction and leads to the onset of the "Bloated" stage (Figure 2a).

During the "Bloated" stage, internal pressure from gas accumulation forces purge fluids to escape from cadaveric orifices (mouth, nose, anus) and flow into the soil. The effect of purge fluid on below-ground ecology is unknown. It is likely that this amendment results in a localized flush of microbial biomass, shift in soil faunal communities, $\mathrm{C}$ mineralization $\left(\mathrm{CO}_{2}-\mathrm{C}\right.$ evolution) and increase in soil nutrient status. This effect would be similar to the formation of discrete "islands of fertility" observed in association with plant (Zaady et al. 1996) and fecal (Willott et al. 2000) resources. Eventually, putrefactive bloating and maggot feeding activity cause ruptures in the skin. These allow oxygen back into the cadaver and expose more surface area for the development of fly larvae and aerobic microbial activity (Putman 1978b) (Figure 2b). This designates the beginning of "Active Decay" (Johnson 1975; Micozzi 1986).

"Active Decay" is characterized by rapid mass loss (Figure 1) resulting from peak maggot activity and the beginning of a substantial release of cadaveric fluids into the soil via skin ruptures and natural orifices (Figure $2 b$ ). This flux of cadaveric material into the soil will connect any islands of fertility resulting from purge fluid and, thus, lead to the formation of a single cadaver decomposition island (CDI). The status of soil nutrients and microbial communities during "Active Decay" is unknown. However, Bornemissza (1957) observed an increase in some members of soil faunal community (Calliphoridae, Histeridae, Ptiliidae, Staphylinidae) and a decrease in numbers of Collembola and Acari beneath a guinea pig (Cavia porcellus L.) cadaver ( $620 \mathrm{~g})$ during "Active Decay," although this decomposition stage was referred to as "Black Putrefaction." "Active Decay" will continue until maggots have migrated from the cadaver to pupate. This phenomenon represents the onset of "Advanced Decay."

The lateral extent of a CDI during "Advanced Decay" is determined by the size of the cadaver, the lateral extent of the maggot mass (including the path of maggot migration: Figure 2c) and soil texture. Soil texture and cadaver size also affect the vertical extent of a CDI. For example, during "Advanced Decay," Coe (1978) observed the CDI in sandy loam soil associated with elephant (Loxodonta africana Blumenbach) $(\sim 1,629 \mathrm{~kg})$ decomposition extending to $40 \mathrm{~cm}$ below the cadaver, $35 \mathrm{~cm}$ at $1 \mathrm{~m}$ from the cadaver, and $8 \mathrm{~cm}$ at $2 \mathrm{~m}$ from the cadaver. No penetration into the soil was observed at $2.2 \mathrm{~m}$ from the cadaver. In contrast, the CDI associated with the decomposition of a $633 \mathrm{~kg}$ elephant cadaver on 
quartz gravel extended to $1.5 \mathrm{~m}$ below the soil surface (Coe 1978). By comparison, the CDI associated with the decomposition of a $620 \mathrm{~g}$ guinea pig (Cavia porcellus L.) extended to $14 \mathrm{~cm}$ below the cadaver in sandy soil (Bornemissza 1957).

A CDI during "Advanced Decay" represents an area of increased soil carbon (Putman 1978b; Vass et al. 1992; Carter 2005), nutrients (Vass et al. 1992; Towne 2000; Carter 2005) and pH (Vass et al. 1992; Carter 2005). These changes are not surprising when we take into account that a cadaver contains a large amount of water $(50 \%$ to $80 \%)$ and has a narrow C:N ratio (Tortora and Grabowski 2000; DeSutter and Ham 2005) (Table 1). These properties are characteristic of a high quality resource that is associated with a significant amount of available C, high level of microbial activity and rapid rate of nutrient input (Swift et al. 1979). These characteristics become magnified upon consideration that, for example, a fresh elephant (Loxodonta africana Blumenbach) cadaver can weigh $1,629 \mathrm{~kg}$ (Coe 1978) while a heap of elephant dung might weigh $4.5 \mathrm{~kg}$ (Anderson and Coe 1974).

Putman $(1976,1978 b)$ observed that approximately
$1 \mathrm{mg} \mathrm{CO}$-C per gram $\left(\mathrm{g}^{-1}\right)$ cadaver (dry weight) was evolved from gravesoil associated with rat (Rattus rattus L.) cadavers. If we assume that the soil microbial biomass assimilates $20-40 \%$ of available C (Smith 1982) then a total of $1.25-2.5 \mathrm{mg} \mathrm{C} \mathrm{g}^{-1}$ cadaver (dry weight) was introduced to the soil during the course of decomposition. After maggot migration, this input was associated with an increase of $1.4-2.7 \mu \mathrm{g} \mathrm{CO}_{2}-\mathrm{C} \mathrm{g}^{-1}$ cadaver (dry weight) per hour $\left(\mathrm{h}^{-1}\right)$ during cold seasons and 41-68 $\mu \mathrm{g} \mathrm{CO}_{2}-\mathrm{C} \mathrm{g}^{-1}$ cadaver (dry weight) $\mathrm{h}^{-1}$ during warm seasons (Putman 1976, 1978b). By comparison to other organic resources, Putman (1983) demonstrated that similar levels of $\mathrm{CO}_{2}-\mathrm{C}$ can evolve during the decomposition of fecal matter (millipede pellets: Glomeris marginata Villers, 1789) (Nicholson et al. 1966) and plant litter (redbud leaves: Cercis canadensis L.) (Witkamp 1966). However, peak levels of microbial activity associated with fecal and plant resources tend to occur immediately after introduction to the soil when the readily available components are accessible. This is in contrast to cadaver decomposition where the majority of readily available energy and nutrients enter the soil after maggot migration (Advanced Decay) (Vass et al. 1992).

Table I. Chemical composition of cadaveric, plant and fecal resources

\begin{tabular}{|c|c|c|c|c|c|c|c|c|}
\hline Organic resource & $\begin{array}{l}\mathrm{H}_{2} \mathrm{O} \\
(\%)\end{array}$ & $\begin{array}{l}\mathrm{C}: \mathrm{N} \\
\text { ratio }\end{array}$ & $\begin{array}{l}\mathrm{N} \\
\left(\mathrm{g} \mathrm{kg}^{-1}\right)\end{array}$ & $\begin{array}{l}P \\
\left(g^{-1} g^{-1}\right)\end{array}$ & $\begin{array}{l}\mathrm{K} \\
\left(\mathrm{g} \mathrm{kg}^{-1}\right)\end{array}$ & $\begin{array}{l}\mathrm{Ca} \\
\left(\mathrm{g} \mathrm{kg}^{-1}\right)\end{array}$ & $\begin{array}{l}\mathrm{Mg} \\
\left(\mathrm{g} \mathrm{kg}^{-1}\right)\end{array}$ & References \\
\hline \multicolumn{9}{|l|}{ Cadaver } \\
\hline Human age: neonate & 69 & - & 19 & 5.6 & 2.1 & 10 & 2.6 & Widdowson (1950) \\
\hline Pig (Sus scrofa L.) age: 56 days & 80 & 7.7 & 26 & 6.5 & 2.9 & 10 & 0.4 & $\begin{array}{l}\text { Spray and Widdowson (1950); } \\
\text { DeSutter and Ham (2005) }\end{array}$ \\
\hline Rat (Rattus rattus L.) age: 70 days & 75 & - & 32 & 6.5 & 3.5 & 12 & 0.5 & Spray and Widdowson (1950) \\
\hline \multicolumn{9}{|l|}{ Plant material } \\
\hline $\begin{array}{l}\text { Barley straw (Hordegum } \\
\text { vulgare L. cv.Welam) }\end{array}$ & - & 94 & 4.5 & - & 13.2 & - & - & Christensen (1985) \\
\hline $\begin{array}{l}\text { Wheat Straw (Triticum } \\
\text { aestivum L. cv. Solid) }\end{array}$ & - & 61 & 7.0 & - & 3.9 & - & - & Christensen (1985) \\
\hline $\begin{array}{l}\text { Norway spruce litter } \\
\quad \text { (Picea abies L. Karst) }\end{array}$ & 7.1 & - & II & 0.9 & 2.2 & 16.6 & 1.0 & Vesterdal (1999) \\
\hline \multicolumn{9}{|l|}{ Fecal matter } \\
\hline Pig manure & - & 16 & 31 & 22 & 11 & 26 & 10 & Bernal and Kirchmann (1992) \\
\hline Poultry manure & - & 25 & 14 & 10 & 11 & - & - & Kaur et al. (2005) \\
\hline Dairy manure & - & 16 & 29 & 14.5 & 14.5 & 14.7 & 5.3 & Gagnon (2004) \\
\hline Cattle manure+urine & - & 16 & 25 & 2.0 & - & - & - & Brouwer and Powell (1998) \\
\hline Cattle manure & 82 & 22.2 & 3.8 & - & - & - & - & Calderón et al. (2005) \\
\hline Cow manure & 84 & 18.2 & 3.9 & - & - & - & - & Calderón et al. (2005) \\
\hline Dairy manure & 85 & 16.2 & 4.7 & - & - & - & - & Calderón et al. (2005) \\
\hline
\end{tabular}


"Advanced Decay" is also associated with a significant increase in the concentration of soil nitrogen. The decomposition of a $68 \mathrm{~kg}$ human cadaver resulted in an increase in approximately $525 \mu \mathrm{g}$ ammonium g ${ }^{-1}$ soil (Vass et al. 1992) by 20 days postmortem. In contrast, the amendment of $10 \mathrm{~g}$ soil with $200 \mathrm{mg}$ fresh pig manure can result in an increase of approximately $110 \mu \mathrm{g}$ inorganic N (ammonium, nitrate) $\mathrm{g}^{-1}$ soil after 63 days (Bernal and Kirchmann 1992) while the introduction of $0.6 \mathrm{~g}$ fresh oat (Avena sativa L.) roots to $150 \mathrm{~g}$ soil (dry weight) resulted in an increase of approximately $22 \mu \mathrm{g}$ inorganic $\mathrm{N} \mathrm{g}^{-1}$ soil over a period of 112 days (Malpassi et al. 2000). It is important to note that the introduction of any organic resource with a C:N ratio of greater than 30:1 (e.g. cereal residues, straw, woody material) (see Table 1) will usually result in an initial decrease in the concentration of soil inorganic nitrogen due to immobilization (uptake of inorganic $\mathrm{N}$ by soil microbes) (e.g. Green et al. 1995). Thus, the C:N ratio will narrow during decomposition and inorganic $\mathrm{N}$ will be released into the soil upon reaching approximately 20:1 (see Swift et al. 1979; Stevenson and Cole 1999). However, $\mathrm{C}$ quality can influence this process such that a high percentage of oxidizable $\mathrm{C}$ can lead to immobilization and low oxidizable $\mathrm{C}$ can result in mineralization (see Smith and Tibbett 2004).

Cadaveric, plant and fecal material contains several other nutrients, such as $\mathrm{P}$, potassium $(\mathrm{K})$, calcium $(\mathrm{Ca})$ and magnesium $(\mathrm{Mg})$ (Table 1), which will enter the soil upon decomposition. Soil $(3-5 \mathrm{~cm})$ beneath a $68 \mathrm{~kg} \mathrm{hu}-$ man cadaver in "Advanced Decay" contained $300 \mu \mathrm{g} \mathrm{K}$ $\mathrm{g}^{-1}$ soil, $50 \mu \mathrm{g} \mathrm{Ca} \mathrm{g}^{-1}$ soil and $\sim 10 \mu \mathrm{g} \mathrm{Mg} \mathrm{g}{ }^{-1}$ soil (Vass et al. 1992). By comparison, the amendment of $100 \mathrm{~g}$ soil with fresh dairy manure at a rate of $200 \mathrm{mg} \mathrm{N} \mathrm{kg}^{-1}$ (see Table 1) resulted in an increase of $14 \mu \mathrm{g} \mathrm{P} \mathrm{g}^{-1}$ soil and $108 \mu \mathrm{g} \mathrm{K} \mathrm{g}^{-1}$ soil, $159 \mu \mathrm{g} \mathrm{Ca} \mathrm{g}^{-1}$ soil and $81 \mu \mathrm{g} \mathrm{\textrm {Mg } \mathrm { g } ^ { - 1 }}$ soil after 91 days (Gagnon 2004). As much as 8 tons of leaf litter per hectare per year can be introduced to the soil surface of a tropical rainforest. Annual inputs per gram of litter can equate to approximately $14 \mathrm{mg} \mathrm{N}$, $0.5 \mathrm{mg} \mathrm{P}, 2 \mathrm{mg} \mathrm{K}, 8 \mathrm{mg} \mathrm{Ca}$, and $2 \mathrm{mg} \mathrm{Mg}$ (Ewel 1976; Scott et al. 1992). These nutrient additions, estimated to have occurred over a period of approximately 110 years, were associated with $81 \mu \mathrm{g} \mathrm{N} \mathrm{g}^{-1}$ soil, $900 \mu \mathrm{g} \mathrm{P} \mathrm{g}^{-1}$ soil, $8 \mu \mathrm{g} \mathrm{K} \mathrm{g}^{-1}$ soil, 2,400 $\mu \mathrm{g} \mathrm{Ca} \mathrm{g}^{-1}$ soil and $365 \mu \mathrm{g} \mathrm{Mg} \mathrm{g}{ }^{-1}$ soil (Scott et al. 1992). While the effect of cadaver decomposition on soil nutrient status can be similar to, or less than, that observed with plant and fecal breakdown, peak nutrient values associated with cadaver decomposition can occur in much less time than required by fecal or plant materials.

While an intense pulse allows for a rapid return of energy and nutrients to the wider ecosystem, it is not always associated with a positive effect on soil biology. Decreased abundance of Collembola $(0-14 \mathrm{~cm})$ and Ac- ari $(0-14 \mathrm{~cm})$ were observed beneath a guinea pig $(\mathrm{Ca}$ via porcellus L.) cadaver (Bornemissza 1957). "Advanced Decay" is also typically associated with the death of underlying and nearby vegetation. The cause of plant death might be due to nitrogen toxicity, smothering by the cadaver, excretion of antibiotics by fly larvae (e.g. Thomas et al. 1999) and/or some unknown factor. The intense pulse of $\mathrm{N}$ associated with cadaver decomposition might also result in a loss of $\mathrm{N}$ from the ecosystem through denitrification, volatilization and leaching.

The transition from "Advanced Decay" to "Dry" to "Remains" is difficult to identify (Payne 1965). Increased plant growth around the edge of the CDI (Figure 2d) (Bornemissza 1957) might act as an indicator of the "Dry" stage while increased plant growth within a CDI might indicate the "Remains" stage. These final stages of cadaver decomposition correspond to a second period of slow cadaver mass loss (Figure 1), which is probably due to the depletion of readily available nutrients and moisture. This does not mean, however, that concentration of nutrients in gravesoil have returned to basal levels. The concentration of phosphorus (Towne 2000), ammonium, potassium, sulfate, calcium, chloride and sodium (Vass et al. 1992) in soil $(3-5 \mathrm{~cm}$ ) associated with the decomposition of a $68 \mathrm{~kg}$ human cadaver can remain as high as $50-150 \mu \mathrm{g} \mathrm{g}^{-1}$ soil above basal levels during "Dry" and "Remains." Towne (2000) observed a concentration of inorganic $\mathrm{N}$ approximately $600 \mu \mathrm{g}$ $\mathrm{g}^{-1}$ soil $(0-10 \mathrm{~cm})$ above basal levels after 1 year of bison (Bos bison L.) decomposition. The effect of cadaver size on $\mathrm{C}$ and $\mathrm{N}$ status becomes clearer upon the observation that soils in the center $(0-5 \mathrm{~cm})$ of an elephant (Loxodonta africana Blumenbach) CDI were observed to comprise $0.76 \% \mathrm{~N}$ and $3.25 \% \mathrm{C}$ after 1 year of decomposition whereas control soils contained $0.05 \%-0.13 \% \mathrm{~N}$ and $0.20 \%-0.52 \%$ C (Coe 1978).

The latter stages of cadaver decomposition were also associated with a decreased abundance of Collembola $(0-2 \mathrm{~cm})$ and Acari $(0-5 \mathrm{~cm})$ (Bornemissza 1957). Conversely, "Dry" and "Remains" can be associated with the formation of fruiting structures of the postputrefaction fungi (Sagara 1995). It is believed that this chemoecological group of fungi fruit in response to the form and concentration of N (Tibbett and Carter 2003). "Early Phase" fungi comprise zygomycetes, deuteromycetes and ascomycetes that fruit in response to high concentrations of ammonia (Yamanaka 1995a,b) from 1 to 10 months after $\mathrm{N}$ addition (Sagara 1992). "Late Phase" postputrefaction fungi fruit in response to organic $\mathrm{N}$ and high concentrations of ammonium and nitrate (Yamanaka 1995a,b) and are present from 1 to 4 years after $\mathrm{N}$ addition (Sagara 1992). These findings, along with the observation that bison (Bos bison L.) (Towne 2000) and muskox (Ovibos moschatus Zimmerman) (Danell et al. 2002) decomposition 
can affect the structure of plant communities for at least 5 and 10 years, respectively, show that a CDI is a longlasting component of terrestrial ecosystems. This is similar to the effect of organic and sulfide enrichment of sediments associated with whale falls in deep-sea marine ecosystems (Smith et al. 1998).

\section{Cadaver Burial and Gravesoil Ecology}

Although the majority of cadavers that die in nature are located on the soil surface, a number of studies were conducted to understand cadaver decomposition after burial in soil (Motter 1898; Mant 1950; Lundt 1964; Payne et al. 1968; Sagara 1976; Lötterle et al. 1982; Rodriguez and Bass 1985; DeGaetano et al. 1992; Child 1995; Spennemann and Franke 1995; VanLaerhoven and Anderson 1999; Hopkins et al. 2000; Fiedler et al. 2004; Carter 2005; Forbes et al. 2005a, 2005a-c; Weitzel 2005; Carter and Tibbett 2006). While the results from these studies might be of little interest to the terrestrial ecologist, this aspect of below-ground ecology merits attention because it might be of significance to the archaeologist, forensic scientist, and those concerned with animal composting or the disposal of farm animals.

The burial of a cadaver in soil restricts the access of most insects and scavengers. The absence of these organisms results in significantly less cadaver decomposition than observed on the soil surface (Rodriguez and Bass 1985; Rodriguez 1997; VanLaerhoven and Anderson 1999; Fiedler and Graw 2003). It is generally accepted that coarse-textured (sandy) soil with a low moisture content frequently promotes desiccation (Mant 1950; Santarsiero et al. 2000; Fiedler and Graw 2003). This phenomenon is almost certainly related to the diffusion of gases through the soil matrix (see Tibbett et al. 2004). Coarse-textured soils are associated with a high rate of gas diffusivity (Moldrup et al. 1997), which allows gases and moisture to move relatively rapidly through the soil matrix. The ability of coarse-textured soil to rapidly lose moisture will also promote desiccation because hydrolytic enzymes associated with the cycling of carbon and nutrients are retarded by low moisture content (Skujins and McLaren 1967). Desiccation can inhibit decomposition and result in the natural preservation of a cadaver for thousands of years (Micozzi 1991). However, this phenomenon only occurs in a few extreme settings such as areas of Egypt (Ruffer 1921; Dzierzykray-Rogalsky 1986), Peru (Allison 1979) and Siberia (Lundin 1978). Alternatively, burial in coarse-textured soil with a high water content might result in the formation of pseudomorphs (shapes of human cadavers primarily in the form of sand), such as those observed at Sutton Hoo, England (Bethell and Carver 1987). These pseudomorphs are associated with an elevated concentration of calcium, phosphorus and manganese, which is likely related to the breakdown of bone.

Fine-textured (clayey) soil was associated with an inhibition of cadaver breakdown (Turner and Wiltshire 1999; Hopkins et al. 2000; Santarsiero et al. 2000). These soils are associated with a low rate of gas diffusivity. The burial of a cadaver in a wet, fine-textured soil can result in decreased decomposition (Turner and Wiltshire 1999; Hopkins et al. 2000) because the rate at which oxygen is exchanged with $\mathrm{CO}_{2}$ might not be sufficient to meet aerobic microbial demand (Carter 2005). Thus, reducing conditions are established whereby anaerobic microorganisms dominate decomposition. These organisms are less efficient decomposers than aerobes (Swift et al. 1979).

Reducing conditions can also promote the formation of adipocere (Fiedler and Graw 2003; see Forbes et al. 2004, 2005b) around a cadaver and/or internal organs, which significantly slows cadaver decomposition (Froentjes 1965; Dent et al. 2004; Fiedler et al. 2004). Many mammals (human, pig, sheep, cow, rabbit) contain sufficient moisture and fat to form adipocere in a moist coarse-textured soil (Forbes et al. 2005a,b). Gravesoil associated with adipocere formation was observed to contain elevated levels of dissolved organic C, plant available P and total P (Fiedler et al. 2004) relative to soils without adipocere. While acidic soil can promote the leaching of P from bone (Eidt 1977), significant amounts can also be released from soil saturated with $\mathrm{P}$ (such as gravesoils) under reducing conditions (Scalenghe et al. 2002). This release is enhanced by the presence of organic carbon, which acts as the primary electron donor (Scalenghe et al. 2002).

Few estimates of soil microbial biomass associated with reducing conditions were reported (Hopkins et al. 2000; Fiedler et al. 2004). Fiedler et al. (2004) observed a decrease in soil microbial biomass carbon estimated using the chloroform-fumigation extraction (CFE) method (Vance et al. 1987; Wu et al. 1990). Hopkins et al. (2000) observed an increase in soil microbial biomass carbon estimated using the substrate-induced respiration (SIR) method (Anderson and Domsch 1978; Hopkins and Ferguson 1994). The reason for this discrepancy is unknown, although a difference in depth of burial was suggested (Fiedler et al. 2004). While it is possible that soil depth might explain this difference it is critical to recognize that each of these methods estimates different fractions of the soil microbial biomass. SIR estimates the biomass of glucose-responsive microbes whereas CFE estimates the extracted carbon associated with fumigation of soil. Thus, it is possible to have a decrease in the whole soil microbial biomass coincide with an increase in glucose-responsive biomass (see Dilly and Munch 1998). It is also important to note that the formation of 
Figure 3. Diagram of the cadaver decomposition island (CDI) as a highly concentrated hub of energy and nutrient flow that contributes to landscape heterogeneity, physical and chemical complexity and biodiversity in a terrestrial ecosystem.

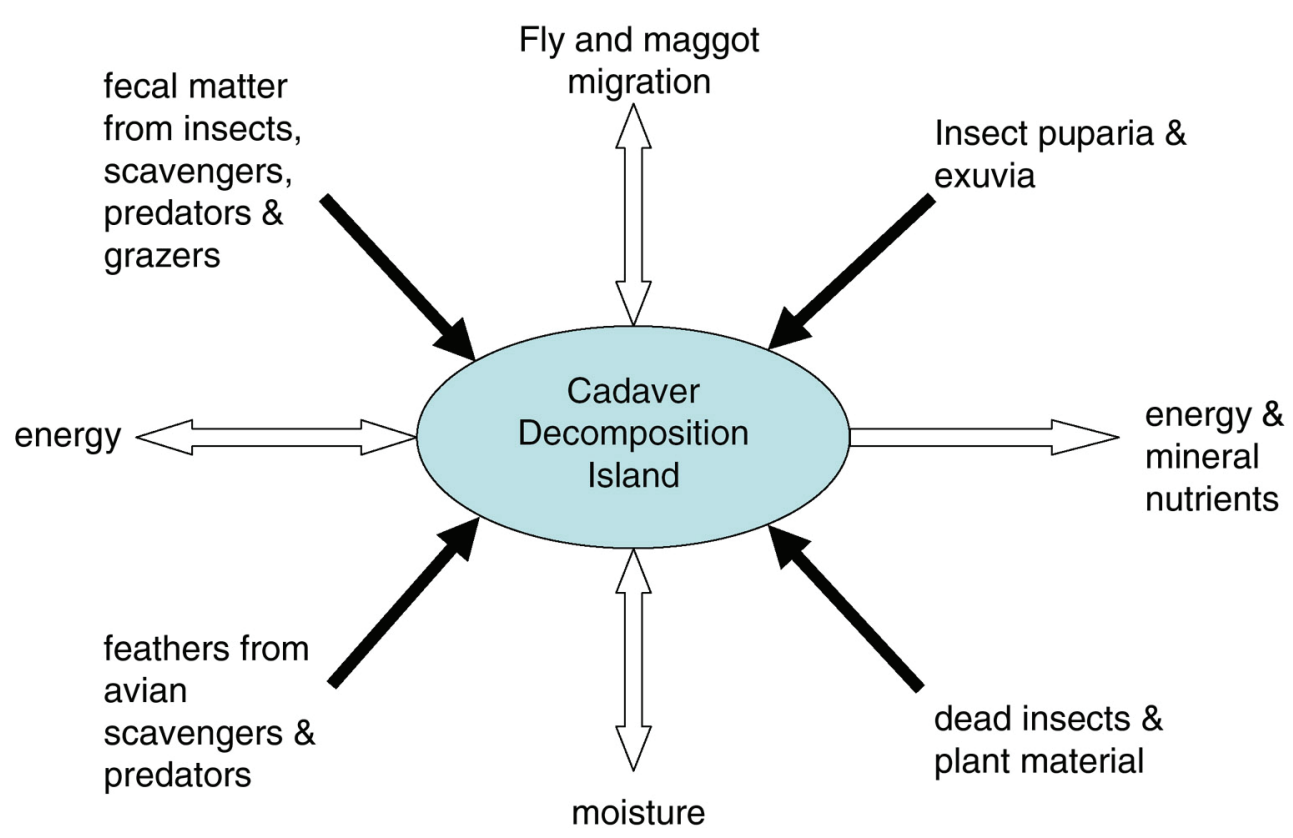

adipocere is not necessarily an endpoint (Evans 1963a; Froentjes 1965). Upon translocation to the soil surface or the establishment of an aerobic environment, adipocere can undergo decomposition (Evans 1963b). This process is typically associated with the bacteria Bacillus spp., Cellulomonas spp. and Nocardia spp. (Pfeiffer et al. 1998).

\section{The Role of Cadaver Decomposition in Terrestrial Ecosystems}

Cadaver decomposition (and the formation of a CDI) is a natural disturbance that can dramatically alter steady-state edaphic and biological characteristics (Hopkins et al. 2000; Towne 2000). This represents a striking example of the linkage between aboveground and below-ground communities whereby the death of aboveground organisms exert positive and negative effects on below-ground organisms (e.g. Gehring et al. 2002; Wardle 2002; Wardle et al. 2004). This linkage almost certainly represents a vital pathway of carbon and nutrients in terrestrial ecosystems (as proposed by Swift et al. (1979), Odum (1959) and Coe (1978)) considering that a substantial number of animals can die from causes other than predation (Coe 1978; Young 1994) leaving their cadavers to decompose and nutrients to be recycled. Although live mammals enrich soils with materials such as feces, hair and antlers, the carbon and nutrients immobilized by a mammal are unavailable to the wider ecosystem until death and decomposition occur (Putman 1983). Because of this, living mammals can be viewed as bottlenecks in the cycling of carbon, nutrients and water (Putman 1983).
Every CDI is a discrete, ephemeral "hot spot" (Parkin 1987; Coleman et al. 2004) of activity, analogous to a rhizosphere and drilosphere, because it represents a small proportion of terrestrial area but accounts for a significant amount of heterotrophic activity within an ecosystem. Much of this activity is directed towards the cycling of cadaveric materials out to the wider ecosystem. However, a CDI also receives additional organic and inorganic materials resulting from the activity of scavengers, grazers and predators. During early stages of cadaver breakdown these inputs might include fecal matter and/or components (hair, nails, feathers) from scavengers. During later stages of decomposition, the soil can be amended with fecal matter from grazers attracted to the enhanced plant growth surrounding a CDI (Towne 2000) or from predators that hunt these grazers (Gray 1993). Insect and avian materials might represent a significant influx of chitin and keratin, respectively. Thus, a CDI acts as a highly concentrated hub of carbon and nutrient flow (Figure 3) that can be scattered across a landscape and, therefore, contribute to landscape complexity and heterogeneity.

The importance of the heterogeneous distribution of cadaveric material in soil cannot be understated as it can facilitate niche provision and hence biodiversity in an ecosystem. A CDI contributes directly to biodiversity by acting as a specialized habitat for the reproduction of the majority of blow flies (Calliphoridae) (Hall 1948), Dermestid (Dermestidae) beetles, carrion beetles (Silphidae) and burying beetles (Silphidae) (Meierhofer et al. 1999; Smith and Merrick 2001). The presence and activity of these insects may affect other trophic levels (bacteria, fungi, protozoa, nematodes). For example, in- 
sects can establish phoretic relationships with a number of nematodes (Poinar 1983; Richter 1993). Furthermore, a CDI supports the establishment of pioneer plant species because the pulse of nutrients and death of vegetation associated with cadaver decomposition is a disturbance of high resource quality and reduced competition (Towne 2000). A change in plant community structure will, in turn, probably affect soil microbial communities (Johnson et al. 2003) and the organisms that feed upon them (e.g. nematodes, protozoa). This cascade effect, as Towne (2000) pointed out, is part of a cycle of disturbance and recovery that has enriched ecosystems for eons.

Cadaveric material has a significant impact on belowground ecology when circumstances allow for in situ decomposition. The breakdown of cadavers and cadaver components (e.g. skeletal muscle tissue, bone) is associated with an increase in soil microbial biomass (Child 1995; Hopkins et al. 2000; Carter and Tibbett 2006), soil microbial activity (Putman 1978b; Hopkins et al. 2000; Carter and Tibbett 2006) and nematode abundance (Todd et al. 2006). Cadaveric breakdown also results in an increase in the concentration of ammonium (Vass et al. 1992; Hopkins et al. 2000; Towne 2000; Carter 2005), phosphorus (Bethell and Carver 1987; Towne 2000), calcium, potassium, sulfate, magnesium, chloride, sodium (Vass et al. 1992) sulfur (Hopkins et al. 2000), manganese (Bethell and Carver 1987) and base cations (Rodriguez and Bass 1985; Vass et al. 1992; Hopkins et al. 2000; Carter 2005).

Clearly, our knowledge of the below-ground ecology of cadaver decomposition is limited. This is in direct contrast with the decomposition of other organic resources such as plant leaves (Webster et al. 2000), stems (Hopkins et al. 2001), root exudates (Dakora and Phillips 2005), seeds (Tibbett and Sanders 2002) and sewage sludge (Ajwa and Tabatabai 1994). This discrepancy is probably because forensic taphonomy has primarily relied upon case studies, anecdotal evidence and unreplicated experiments for data (Mant 1950; MorovicBudak 1965; Sagara 1976; Rodriguez and Bass 1985; Micozzi 1986; Galloway et al. 1989; Mann et al. 1990; Prieto et al. 2004). Techniques commonplace in ecological research should be applied to the materials relevant to forensic taphonomy (cadavers, cadaver components). A long-term goal of this research should be to more accurately account for the contribution of cadaver decomposition to the cycling of carbon and nutrients in terrestrial ecosystems. Since the majority of decomposition in soil is microbially mediated (Moorhead and Reynolds 1989) future investigations might focus on below-ground community assemblages and succession. Several techniques are currently used for studying soil microbial communities (Kirk et al. 2004). These can provide a pro- file of the whole soil community (such as via fatty acid methyl esters (Drijber et al. 2000) or phospholipid fatty acid methyl esters (Pankhurst et al. 2001; Carter 2005), bacterial community (Horswell et al. 2002), or individual species (Rhodes et al. 1998). A molecular approach to the study of microbial diversity has proven helpful in the investigation of sediments associated with whale falls (Tringe et al. 2005).

A fundamental understanding of gravesoil ecology should, in turn, contribute to forensic taphonomy by designating biological and chemical markers with the potential to aid in the location or dating of clandestine graves such as the fruiting sequence of postputrefaction fungi (Carter and Tibbett 2003) or the nutrient concentration of gravesoils (Vass et al. 1992). Forensic science could benefit from the development of a method to estimate postmortem interval after 1,285 ADDs, when the concentration of volatile fatty acids (propionic, valeric, butyric) returns to basal levels (Vass et al. 1992). This work would likely require investigating the postputrefaction fungi, ratios of the longer chained FAMEs, or possibly examining the community dynamics of microfungi (e.g. Lumley et al. 2001). Some strains of microfungi are capable of breaking down keratin, which is the primary component of hair and nails. As such, this component is likely to represent a significant portion of available carbon and nutrients during "Remains" stage decomposition. Whatever research paths are taken, it is clear that gravesoil ecology and the ecology of other ephemeral resource patches (Blaustein and Schwartz 2001; Finn 2001; De Meester et al. 2005) has the potential to become a key area of study in terms of the cycling of carbon and nutrients, soil organic matter formation and the relationship between biodiversity and ecosystem function.

Acknowledgments - We thank S. Forbes, L. Higley, T. Huntington, P. Mullin and G. Towne for the informative discussion during the preparation of the manuscript. This paper is a contribution of the University of Nebraska Agricultural Research Division, Journal Series Number 15209.

\section{References}

Aarons SR, O'Connor CR, Gourley CJP (2004) Dung decomposition in temperate dairy pastures. I. Changes in soil chemical properties. Aust J Soil Res 42:107-114

Ajwa HA, Tabatabai MA (1994) Decomposition of different organic materials in soils. Biol Fertil Soils 18:175-182

Allee WC, Emerson AE, Park O, Park T, Schmidt KP (1949) Principles of Animal Ecology. W. B. Saunders Co., Philadelphia, PA, USA

Allison M (1979) Paleopathology in Peru. Nat Hist 88:74-83

Amendt J, Krettek R, Zehner R (2004) Forensic entomology. Naturwissenschaften 91:51-65 
Anderson JM, Coe MJ (1974) Decomposition of elephant dung in a arid, tropical environment. Oecologia 14:111-125

Anderson JPE, Domsch KH (1978) A physiological method for the quantitative measurement of microbial biomass in soils. Soil Biol Biochem 10:215-221

Anderson GS, VanLaerhoven SL (1996) Initial studies on insect succession on carrion in southwest British Columbia. J Forensic Sci 41:617-625

Aturaliya S, Lukasewycz A (1999) Experimental forensic and bioanthropological aspects of soft tissue taphonomy: 1. Factors influencing postmortem tissue desiccation rate. J Forensic Sci 44:893-896

Baco AR, Smith CR (2003) High species richness in deep-sea chemoautotrophic whale skeleton communities. Mar Ecol Prog Ser 260:109-114

Beijerinck M (1913) De infusies en de ontdekking der backterien. Muller, Amsterdam

Bernal MP, Kirchmann H (1992) Carbon and nitrogn mineralization and ammonia volatilization from fresh, aerobically and anaerobically treated pig manure during incubation with soil. Biol Fertil Soils 13:135-141

Bethell PH, Carver MOH (1987) Detection and enhancement of decayed inhumations at Sutton Hoo. In: Boddington A, Garland AN, Janaway RC (eds) Death, Decay and Reconstruction: Approaches to Archaeology and Forensic Science. Manchester University Press, Manchester, UK, pp10-21

Bennett BA, Smith CR, Glaser B, Maybaum HL (1994) Faunal community structure of a chemoautotrophic assemblage on whale bones in the deep northeast Pacific Ocean. Mar Ecol Prog Ser 108:205-223

Bjornlund L, Christensen S (2005) How does litter quality and site heterogeneity interact on decomposer food webs of a semi-natural forest? Soil Biol Biochem 37:203-213

Blaustein L, Schwartz SS (2001) Why study ecology in temporary pools? Isr J Zool 47:303-312

Bornemissza GF (1957) An analysis of arthropod succession in carrion and the effect of its decomposition on the soil fauna. Aust J Zool $5: 1-12$

Brouwer J, Powell JM (1998) Increasing nutrient use efficiency in West-African agriculture: The impact of micro-topography on nutrient leaching from cattle and sheep manure. Agric Ecosyst Environ $71: 229-239$

Calderón FJ, McCarty GW, Reeves III JB (2005) Analysis of manure and soil nitrogen mineralization during incubation. Biol Fertil Soils 41:328-336

Campobasso CP, Di Vella G, Introna F (2001) Factors affecting decomposition and Diptera colonization. Forensic Sci Int 120:18-27

Carter DO (2005). Forensic taphonomy: Processes associated with cadaver decomposition in soil. Ph.D. thesis, James Cook University

Carter DO, Tibbett M (2003) Taphonomic mycota: Fungi with forensic potential. J Forensic Sci 48:168-171

Carter DO, Tibbett M (2006) The decomposition of skeletal muscle tissue (Ovis aries) in a sandy loam soil incubated at different temperatures. Soil Biol Biochem 38:1139-1145

Child AM (1995) Towards an understanding of the microbial decomposition of archaeological bone in the burial environment. J Archaeol Sci 22:165-174

Christensen BT (1985) Wheat and barley straw decomposition under field conditions: effect of soil type and plant cover on weight loss, nitrogen and potassium content. Soil Biol Biochem 17:691-697

Clark MA, Worrell MB, E. PJ (1997) Postmortem changes in soft tissue. In: Haglund WD, Sorg MH (eds) Forensic Taphonomy: The Postmortem Fate of Human Remains. CRC Press, Boca Raton, FL, USA, pp151-164

Coe J (1973) Postmortem chemistry: Practical considerations and a re- view of literaure. J Forensic Sci 19:13-32

Coe M (1978) The decomposition of elephant carcases in the Tsavo (East) National Park, Kenya. J Arid Environ 1:71-86

Coleman DC, Crossley Jr. DA, Hendrix PF (2004) Fundamentals of Soil Ecology. 2nd edn. Elsevier Acadamic Press, Burlington, MA, USA

Crist TAJ, Washburn A, Park H, Hood I, Hickey MA (1997) Cranial bone displacement as a taphonomic process in potential child abuse cases. In: Haglund WD, Sorg MH (eds) Forensic Taphonomy: The Postmortem Fate of Human Remains. CRC Press, Boca Raton, FL, USA, pp319-336

Dakora FD, Phillips DA (2005) Root exudates as mediators of mineral acquisition in low-nutrient environments. Plant Soil 245:35-47

Danell K, Berteaux D, Braathen KA (2002) Effect of muskox carcasses on nitrogen concentration in tundra vegetation. Arctic 55:389-392

De Meester L, Declerck S, Stoks R, Louette G, van de Meutter F, De Bie T, Michels E, Brendonck L (2005) Ponds and pools as model systems in conservation biology, ecology and evolutionary biology. Aquat Conserv 15:715-725

DeGaetano DH, Kempton JB, Rowe WF (1992) Fungal tunneling of hair from a buried body. J Forensic Sci 37:1048-1054

Dent BB, Forbes SL, Stuart BH (2004) Review of human decomposition processes in soil. Environ Geol 45:576-585

DeSutter TM, Ham JM (2005) Lagoon-biogas emissions and carbon balance estimates of a swine production facility. J Environ Qual 34:198-206

DeVault TL, Rhodes OE, Shivik JA (2003) Scavenging by vertebrates: Behavioral, ecological and evolutionary perspectives on an important energy transfer pathway in terrestrial ecosystems. Oikos 102:225-234

DeVault TL, Brisbin Jr. IL, Rhodes OE (2004) Factors influencing the acquisition of rodent carrion by vertebrate scavengers and decomposers. Can J Zool 82:502-509

Dilly O, Munch J-C (1998) Ratios between estimates of microbial biomass content and microbial activity in soils. Biol Fertil Soils 27:374-379

Drijber RA, Doran JW, Parkhurst AM, Lyon DJ (2000) Changes in soil microbial community structure with tillage under long-term wheat-fallow management. Soil Biol Biochem 32:1419-1430

Dzierzykray-Rogalsky T (1986) Natural mummification in Egypt. In: David AR (ed) Science in Egyptology. Manchester University Press, Manchester, UK, pp101-112

Efremov EA (1940) Taphonomy: A new branch of paleontology. PanAmer Geol 74:81-93

Eidt RC (1977) Detection and examination of Anthrosols by phosphate analysis. Science 4311:1327-1333

Eisenberg JF, Thorington Jr. RW (1973) A preliminary analysis of a neotropical mammal fauna. Biotropica 5:150-161

Esse PC, Buerkert A, Hiernaux P, Assa A (2001) Decomposition of and nutrient release from ruminant manure on acid sandy soils in the Sahelian zone of Niger, West Africa. Agric Ecosyst Environ 83:55-63

Evans WED (1963a) Adipocere formation in a relatively dry environment. Med Sci Law 3:145-153

Evans WED (1963b) The Chemistry of Death. Charles C. Thomas, Springfield, IL, USA

Ewel JJ (1976) Litter fall and leaf decomposition in a tropical forest succession in eastern Guatemala. J Ecol 64:293-308

Fang C, Smith P, Smith JU (2005) A simple equation for simulating C decomposition in a multi-component pool of soil organic matter. Eur J Soil Sci 56:815-820

Fiedler S, Graw M (2003) Decomposition of buried corpses, with special reference to the formation of adipocere. Naturwissenschaften 90:291-300 
Fiedler S, Schneckenberg K, Graw M (2004) Characterization of soils containing adipocere. Arch Environ Contam Toxicol 47:561-568

Finn JA (2001) Ephemeral resource patches as model systems for diversity-function experiments. Oikos 92:363-366

Fitter AH, Gilligan CA, Hollingworth K, Kleczkowski A, Twyman RM, Pitchford JW (2005) Biodiversity and ecosystem function in soil. Funct Ecol 19:369-377

Forbes SL, Stuart BH, Dadour IR, Dent BB (2004) A preliminary investigation of the stages of adipocere formation. J Forensic Sci 49:566-574

Forbes SL, Dent BB, Stuart BH (2005a) The effect of soil type on adipocere formation. Forensic Sci Int 154:35-43

Forbes SL, Stuart BH, Dent BB (2005b) The effect of burial environment of adipocere formation. Forensic Sci Int 154:24-34

Forbes SL, Stuart BH, Dent BB (2005c) The effect of the burial method on adipocere formation. Forensic Sci Int 154:44-52

Forbes SL, Stuart BH, Dent BB, Fenwick-Mulcahy S (2005d) Characterization of adipocere formation in animal species. J Forensic Sci 50:633-640

France DL, Griffin TJ, Swanburg JG, Lindemann JW, Davenport GC, Trammell V, Travis CT, Kondratieff B, Nelson A, Castellano K, Hopkins D (1992) A mutidisciplinary approach to the detection of clandestine graves. J Forensic Sci 37:1445-1458

France DL, Griffin TJ, Swanburg JG, Lindemann JW, Davenport GC, Trammell V, Travis CT, Kondratieff B, Nelson A, Castellano K, Hopkins D, Adair T (1997) NecroSearch revisited: Further multidisciplinary approaches to the detection of clandestine graves. In: Haglund WD, Sorg MH (eds) Forensic Taphonomy: The Postmortem Fate of Human Remains. CRC Press, Boca Raton, FL, USA, pp497-509

Froentjes W (1965) Kurzer Bericht über die unvollständige Leichenzersetzung auf Friedhöfen und die Adipocirebildung. Dtsch Z Gesamte Gerichtl Med 56:205-207

Fuller ME (1934) The insect inhabitants of carrion: A study in animal ecology. Council for Scientific and Industrial Research Bulletin no. 82:1-62

Gagnon B (2004) Contribution of on-farm and industrial composts to soil $\mathrm{pH}$ and enrichment in available nutrients and metals. Can J Soil Sci 84:439-445

Galloway A, Birkby WH, Jones AM, Henry TE, Parks BO (1989) Decay rates of human remains in an arid environment. J Forensic Sci 34:607-616

Gehring CA, Wolf JE, Theimer TC (2002) Terrestrial vertebrates promote arbuscular mycorrhizal fungal diversity and inoculum potential in a rain forest soil. Ecol Lett 5:540-548

Gill-King H (1997) Chemical and ultrastructural aspects of decomposition. In: Haglund WD, Sorg MH (eds) Forensic Taphonomy: The Postmortem Fate of Human Remains. CRC Press, Boca Raton, FL, USA, pp93-108

Gray DR (1993) The use of muskox kill sites as temporary rendezvous sites by arctic wolves with pups in early winter. Arctic 46:324-330

Green CJ, Blackmer AM, Horton R (1995) Nitrogen effects on conservation of carbon during corn residue decomposition in soil. Soil Sci Soc Am J 59:453-459

Haglund WD, Sorg MH (1997) Introduction to forensic taphonomy. In: Haglund WD, Sorg MH (eds) Forensic Taphonomy: The Postmortem Fate of Human Remains. CRC Press, Boca Raton, FL, USA, pp1-9

Hall DG (1948) The Blow Flies of North America. Entomological Society of America, Lanham, MD, USA

Haynes G (1980) Prey, bones and predators: potential ecological information from analysis of bone sites. Ossa 7:75-97

Hewadikaram KA, Goff ML (1991) Effect of carcass size on rate of de- composition and arthropod succession patterns. Am J Forensic Med Pathol 12:235-240

Higley LG, Haskell NH (2001) Insect development and forensic entomology: the utility of arthropods in legal investigations. In: Byrd JJ, Castner JL (eds) Forensic Entomology. CRC Press, Boca Raton, FL, USA, pp287-302

Holdaway FG (1930) Field populations and natural control of Lucilia sericata. Nature 126:648-649

Hopkins DW, Ferguson KE (1994) Substrate induced respiration in soil amended with different amino acid isomers. Appl Soil Ecol 1:75-81

Hopkins DW, Wiltshire PEJ, Turner BD (2000) Microbial characteristics of soils from graves: An investigation at the interface of soil microbiology and forensic science. Appl Soil Ecol 14:283-288

Hopkins DW, Webster EA, Chudek JA, Halpin C (2001) Decomposition in soil of tobacco plants with genetic modifications to lignin biosynthesis. Soil Biol Biochem 33:1455-1462

Horswell J, Cordiner SJ, Maas EW, Martin TM, Sutherland BW, Speir TW, Nogales B, Osborn A (2002) Forensic comparison of soils by bacterial community DNA profiling. J Forensic Sci 47:350-353

Houston DC (1985) Evolutionary ecology of Afrotropical and Neotropical vultures in forests. In: Foster M (ed) Neotropical Ornithology. American Ornithologists' Union Monograph No. 36, Washington DC, USA, pp. 856-864

Hunter J (1994) Forensic archaeology in Britain. Antiquity 68:758-769

Illingworth JF (1926) Insects attracted to carrion in southern California. Proc Hawaii Entomol Soc 6:397-401

Janzen DH (1977) Why fruits rot, seeds mold, and meat spoils. Am Natural 111:691-713

Janzen HH (2006) The soil carbon delimma: Shall we hoard it or use it? Soil Biol Biochem 38:419-424

Jenkinson DS (1977) The soil biomass. NZ Soil News 25:213-218

Johnson MD (1975) Seasonal and microseral variations in the insect populations on carrion. Am Midl Nat 93:79-90

Johnson D, Booth RE, Whiteley AS, Bailey MJ, Read DJ, Grime JP, Leake JR (2003) Plant community composition affects the biomass, activity and diversity of microorganisms in limestone grassland soil. Eur J Soil Sci 54:671-678

Kaur K, Kapoor KK, Gupta AP (2005) Impact of organic manures with and without mineral fertilizers on soil chemical and biological properties under tropical conditions. Journal of Plant Nutrition and Soil Science 168:117-122

Kirk JL, Beaudette LA, Hart M, Moutoglis P, Klironomos JN, Lee H, Trevors JT (2004) Methods of studying soil microbial diversity. J Microbiol Methods 58:169-188

Kocárek P (2003) Decomposition and Coleoptera succession on exposed carrion of small mammal in Opava, Czech Republic. Eur J Soil Biol 39:31-45

Linnaeus C (1767) Systema naturae. 12th edn. Laurentius Salvius, Stockholm, Sweden

Lötterle J, Schmierl G, Schellmann B (1982) Einfluss der Bodenart auf die Leichendepomposition bei langen Liegezeiten. Beitr Gerichtl Med 40:197-201

Lumley TC, Gignac LD, Currah RS (2001) Microfungus communities of white spruce and trembling aspen logs at different stages of decay in disturbed and undisturbed sites in the boreal mixedwood region of Alberta. Can J Bot 79:76-92

Lundin RF (1978) "Baby mammoth Dima": A new discovery. J Paleontol 52:941-942

Lundt VH (1964) Ökologische Untersuchungen über die tierische Besiedlung von Aas im Boden. Pedobiologia 4:158-180

Malpassi RN, Kaspar TC, Parkin TB, Cambardella CA, Nubel NA (2000) Oat and rye root decomposition effects on nitrogen miner- 
alization. Soil Sci Soc Am J 64:208-215

Mann RW, Bass MA, Meadows L (1990) Time since death and decomposition of the human body: Variables and observations in case and experimental field studies. J Forensic Sci 35:103-111

Mant AK (1950). A study in exhumation data. M.D. thesis, London University

McCann KS (2000) The diversity-stability debate. Nature 405:228-233

Megyesi MS, Nawrocki SP, Haskell NH (2005) Using accumulated degree-days to estimate the postmortem interval from decomposed human remains. J Forensic Sci 50:618-626

Meierhofer I, Schwarz HH, Müller JK (1999) Seasonal variation in parental care, offspring development, and reproductive success in burying beetle, Nicrophorus vespillo. Ecol Entomol 24:73-79

Melis C, Teurlings I, Linnell JDC, Andersen R, Bordoni A (2004) Influence of a deer carcass on Coleopteran diversity in a Scandinavian boreal forest: A preliminary study. Eur J Wildl Res 50:146-149

Michelsen A, Andersson M, Jensen M, Kjøller A, Gashew M (2004) Carbon stocks, soil respiration and microbial biomass in fire-prone tropical grassland, woodland and forest ecosystems. Soil Biol Biochem 36:1707-1717

Micozzi MS (1986) Experimental study of postmortem change under field conditions: Effects of freezing, thawing and mechanical injury. J Forensic Sci 31:953-961

Micozzi MS (1991) Postmortem Change in Human and Animal Remains: A Systematic Approach. Charles C. Thomas, Springfield, IL, USA

Moldrup P, Olesen T, Rolston DE, Yamaguchi T (1997) Modeling diffusion and reaction in soils: VII. Predicting gas and ion diffusivity in undisturbed and sieved soils. Soil Sci 162:632-640

Moorhead DL, Reynolds JF (1989) The contribution of abiotic processes to buried litter decomposition in the northern Chihuahuan desert. Oecologia 79:133-135

Moran KK, Six J, Horwath WR, van Kessel C (2005) Role of mineralnitrogen in residue decomposition and stable soil organic matter formation. Soil Sci Soc Am J 69:1730-1736

Morovic-Budak A (1965) Experiences in the process of putrefaction in corpses buried in earth. Med Sci Law 5:40-43

Motter MG (1898) A contribution to the study of the fauna of the grave. A study of one hundred and fifty disinterments, with some additional experimental observations. J New York Entomol Soc 6:201-231

Nicholson PB, Bocock KL, Heal OW (1966) Studies on the decomposition of the fecal pellets of a millipede (Glomeris marginata (Villers)). J Ecol 54:755-766

Nuorteva P (1977) Sarcosaprophagous insects as forensic indicators. In: Tedeschi CG, Eckert WG, Tedeschi LG (eds) Forensic Medicine: A Study in Trauma and Environmental Hazards. W. B. Saunders Co., Philadelphia, PA, USA

Odum EP (1959) Fundamentals of Ecology. W. B. Saunders Co., Philadelphia, PA, USA

Pankhurst CE, Yu S, Hawke BG, Harch BD (2001) Capacity of fatty acid profiles and substrate utilization patterns to describe differences in soil microbial communities associated with increased salinity or alkalinity at three locations in South Australia. Biol Fertil Soils 33:204-217

Parkin TB (1987) Soil microsites as a source of denitrification variability. Soil Sci Soc Am J 51:1194-1199

Payne JA (1965) A summer carrion study of the baby pig Sus scrofa Linnaeus. Ecology 46:592-602

Payne JA, King EW (1968) Coleoptera associated with pig carrion. Entomol Monthly Mag 105:224-232

Payne JA, King EW, Beinhart G (1968) Arthropod succession and decomposition of buried pigs. Nature 219:1180-1181
Pfeiffer S, Milne S, Stevenson RM (1998) The natural decomposition of adipocere. J Forensic Sci 43:368-370

Poinar GO (1983) The Natural History of Nematodes. Prentice Hall, Inc., Englewood Cliffs, NJ

Prieto JL, Magaña C, Ubelaker DH (2004) Interpretation of postmortem change in cadavers in Spain. J Forensic Sci 49:918-923

Putman RJ (1976). Energetics of decomposition of animal carrion. Ph.D. thesis, Oxford University

Putman RJ (1977) Dynamics of the blowfly, Calliphora erythrocephala, within carrion. J Anim Ecol 46:853-866

Putman RJ (1978a) Flow of energy and organic matter from a carcase during decomposition. Decomposition of small mammal carrion in temperate systems 2. Oikos 31:58-68

Putman RJ (1978b) Patterns of carbon dioxide evolution from decaying carrion. Decomposition of small mammal carrion in temperate systems 1 . Oikos 31:47-57

Putman RJ (1983) Carrion and Dung: The Decomposition of Animal Wastes. The Institute of Biology's Studies in Biology no. 165. Edward Arnold Ltd, London

Reed HB (1958) A study of dog carcass communities in Tennessee, with special reference to the insects. Am Midl Nat 59:213-245

Rhodes AN, Urbance JW, Youga H, Corlew-Newman H, Reddy CA, Klug MJ, Tiedje JM, Fisher DC (1998) Identification of bacterial isolates obtained from intestinal contents associated with 12,000-year-old mastodon remains. Appl Environ Microbiol 64:651-658

Richards EN, Goff ML (1997) Arthropod succession on exposed carrion in three contrasting tropical habitats on Hawaii Island, Hawaii. J Med Entomol 34:328-339

Richter S (1993) Phoretic association between the dauerjuveniles of Rhabditis stammeri (Rhabditidae) and life history stages of the burying beetle Nicrophorus vespilloides (Coleoptera: Silphidae). Nematologica 39:346-355

Rodriguez WC (1997) Decomposition of buried and submerged bodies. In: Haglund WD, Sorg MH (eds) Forensic Taphonomy: The Postmortem Fate of Human Remains. CRC Press, Boca Raton, FL, USA, pp. 459-468

Rodriguez WC, Bass WM (1983) Insect activity and its relationship to decay rates of human cadavers in east Tennessee. J Forensic Sci 28:423-432

Rodriguez WC, Bass WM (1985) Decomposition of buried bodies and methods that may aid in their location. J Forensic Sci 30:836-852

Ruffer MA (1921) Studies in the Paleopathology of Egypt. University of Chicago Press, Chicago, USA

Sagara N (1976) Presence of buried mammalian carcass indicated by fungal fruiting bodies. Nature 262:816

Sagara N (1992) Experimental disturbances and epigeous fungi. In: Carroll GC, Wicklow DT (eds) The Fungal Community: Its Organization and role in the ecosystem. Marcel Dekker, Inc., New York, NY, USA, pp. 427-454

Sagara N (1995) Association of ectomycorrhizal fungi with decomposed animal wastes in forest habitats: A cleaning symbiosis? Can J Bot 73(Suppl. 1):S1423-S1433

Santarsiero A, Minelli L, Cutilli D, Cappielo G (2000) Hygienic aspects related to burial. Microchem J 67:135-139

Scalenghe R, Edwards AC, Marsan FA, Barberis E (2002) The effect of reducing conditions on the solubility of phosphorus in a diverse range of European agricultural soils. Eur J Soil Sci 53:439-447

Schoenly K, Reid W (1987) Dynamics of heterotrophic succession in carrion arthropod assemblages: Discrete seres or a continuum of change. Oecologia 73:192-202

Scott DA, Proctor J, Thompson J (1992) Ecological studies on a lowland evergreen rain forest on Maracá Island, Roraima, Brazil. II. 
Litter and nutrient cycling. J Ecol 80:705-717

Sinsabaugh RL, Carreiro MM, Alvarez S (2002) Enzyme and microbial dynamics of litter decomposition. In: Burns RG, Dick RP (eds) Enzymes in the Environment: Activity, Ecology and Applications. Marcel Dekker, New York, pp249-265

Skujins JJ, McLaren AD (1967) Enzyme reaction rates at limited water activities. Science 158:1569-1570

Smith OL (1982) Soil Microbiology: A Model of Decomposition and Nutrient Cycling. CRC Press, Boca Raton, FL

Smith CR, Baco AR (2003) Ecology of whale falls at the deep-sea floor. Oceanogr Mar Biol 41:311-354

Smith RJ, Merrick MJ (2001) Resource availability and population dynamics of Nicrophorus investigator, an obligate carrion breeder. Ecol Entomol 26:173-180

Smith M, T., E., Tibbett M (2004). Nitrogen dynamics under Lolium perenne after a single application of three different sewage sludge types from the same treatment stream. Ph.D. thesis, Bournemouth University, UK

Smith CR, Maybaum HL, Baco AR, Pope RH, Carpenter D, Yager PL, Macko SA, Deming JW (1998) Sediment community structure around a whale skeleton in the deep Northeast Pacific: Macrofaunal, microbial and bioturbation effects. Deep-Sea Res Part 2 Top Stud Oceanogr 45:335-364

Spennemann DHR, Franke B (1995) Decomposition of buried human bodies and associated death scene materials on coral atolls in the tropical Pacific. J Forensic Sci 40:356-367

Spray CM, Widdowson EM (1950) The effect of growth and development on the composition of mammals. Brit J Nutr 4:332-353

Stevenson FJ, Cole MA (1999) Cycles of Soil: Carbon, Nitrogen, Phosphorus, Sulfur, Micronutrients. Wiley, Inc., New York, NY, USA

Swift MJ, Heal OW, Anderson JM (1979) Decomposition in Terrestrial Ecosystems. Blackwell Scientific, Oxford

Thomas S, Andrews A, Hay P, Bourgoise S (1999) The antimicrobial activity of maggot secretions: results of a preliminary study. J Tissue Viab 9:127-132

Tibbett M, Carter DO (2003) Mushrooms and taphonomy: The fungi that mark woodland graves. Mycologist 17:20-24

Tibbett M, Sanders FE (2002) Ectomycorrhizal symbiosis enhances plant nutrition through improved access to discrete organic matter nutrient patches of high resource quality. Ann Bot 89:783-789

Tibbett M, Carter DO, Haslam T, Major R, Haslam R (2004) A laboratory incubation method for determining the rate of microbiological degradation of skeletal muscle tissue in soil. J Forensic Sci 49:560-565

Todd TC, Powers TO, Mullin PG (2006) Sentinel nematodes of landuse change and restoration. J Nematol 38(1):20-27

Tortora GJ, Grabowski SR (2000) Principles of Anatomy and Physiology. 9th edn. Wiley, Inc., New York

Towne EG (2000) Prairie vegetation and soil nutrient responses to ungulate carcasses. Oecologia 122:232-239

Tringe SG, von Mering C, Kobayashi A, Salamov AA, Chen K, Chang HW, Podar M, Short JM, Mathur EJ, Detter JC, Bork P, Hugenholtz P, Rubin EM (2005) Comparative metagenomics of microbial communities. Science 308:554-557

Turner BD, Wiltshire PEJ (1999) Experimental validation of forensic evidence: A study of the decomposition of buried pigs in a heavy clay soil. Forensic Sci Int 101:113-122
Vance ED, Brookes PC, Jenkinson DS (1987) An extraction method for measuring soil microbial biomass C. Soil Biol Biochem 19:703-707

VanLaerhoven SL, Anderson GS (1999) Insect succession on buried carrion in two biogeoclimatic zones of British Columbia. J Forensic Sci 44:32-43

Vass AA, Bass WM, Wolt JD, Foss JE, Ammons JT (1992) Time since death determinations of human cadavers using soil solution. J Forensic Sci 37:1236-1253

Vass AA, Barshick S-A, Sega G, Caton J, Skeen JT, Love JC, Synstelien JA (2002) Decomposition chemistry of human remains: A new methodology for determining the postmortem interval. J Forensic Sci 47:542-553

Vesterdal L (1999) Influence of soil type on mass loss and nutrient release from decomposing foliage litter of beech and Norway spruce. Can J For Res 29:95-105

Wardle DA (2002) Communities and Ecosystems: Linking the AboveGround and Below-Ground Components. Princeton University Press, Princeton, NJ, USA

Wardle DA, Nicholson KS, Rahman A (1994) Influence of herbicide applications on the decomposition, microbial biomass, and microbial activity of pasture shoot and root litter. NZ J Agric Res 37:29-39

Wardle DA, Bardgett RD, Klironomos JN, Setälä H, van der Putten WH, Wall DH (2004) Ecological linkages between above-ground and below-ground biota. Science 304:1629-1633

Webster EA, Chudek JA, Hopkins DW (2000) Carbon transformations during decomposition of different components of plant leaves in soil. Soil Biol Biochem 32:301-314

Weitzel MA (2005) A report of decomposition rates of a special burial type in Edmonton, Alberta from an experimental field study. J Forensic Sci 50:641-647

Widdowson EM (1950) Chemical composition of newly born mammals. Nature 166:626-628

Willey P, Snyder LM (1989) Canid modification of human remains: Implications for time-since-death estimations. J Forensic Sci 34:894-901

Willott SJ, Miller AJ, Incoll LD, Compton SG (2000) The contribution of rabbits (Oryctolagus cuniculus L.) to soil fertility in semi-arid Spain. Biol Fertil Soils 31:379-384

Witkamp M (1966) Decomposition of leaf litter in relation to environment, microflora, and microbial respiration. Ecology 47:194-201

Wu J, Joergensen RJ, Pommerening B, Chaussod R, Brookes PC (1990) Measurement of soil microbial biomass by fumigation extraction - An automated procedure. Soil Biol Biochem 22:1167-1169

Yamanaka T (1995a) Changes in organic matter composition of forest soil treated with a large amount of urea to promote ammonia fungi and the abilities of these fungi to decompose organic matter. Mycoscience 36:17-23

Yamanaka T (1995b) Nitrification in a Japanese red pine forest soil treated with a large amount of urea. Journal of the Japanese Forestry Society 77:232-238

Young TP (1994) Natural die-offs of large mammals: Implications for conservation. Conserv Biol 8:410-418

Zaady E, Groffman PM, Sahachak M (1996) Litter as a regulator of N and $\mathrm{C}$ dynamics in macrophytic patches in Negev desert soils. Soil Biol Biochem 28:39-46 